
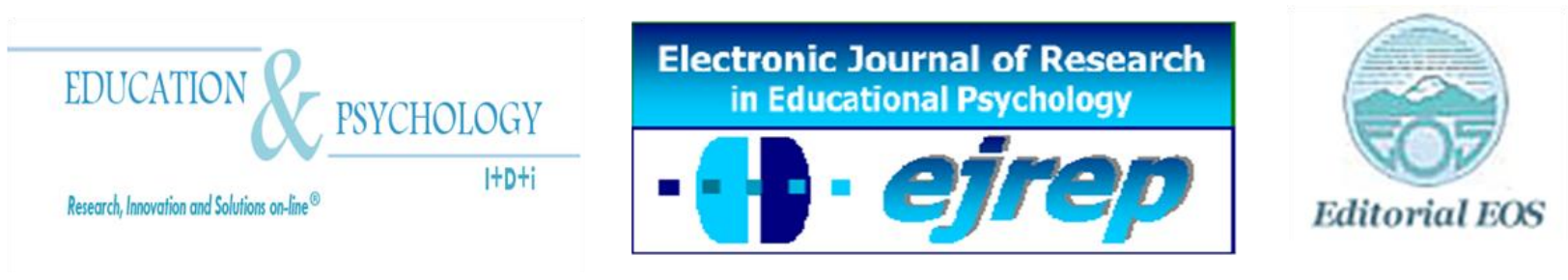

\title{
The role of unconscious information processing in the acquisition and learning of instructional messages
}

\section{Seffetullah Kuldas ${ }^{1}$, Zainudin Abu Bakar ${ }^{2}$, Hairul Nizam Ismail ${ }^{3}$}

${ }^{1}$ School of Educational Studies, Universiti Sains Malaysia, Penang ${ }^{2}$ Department of Social Science Education, Universiti Teknologi Malaysia, Johor

${ }^{3}$ School of Educational Studies, Universiti Sains Malaysia, Penang

\section{Malaysia}

Correspondence: Seffetullah Kuldas, School of Educational Studies, Universiti Sains Malaysia, 11800, Penang, Malaysia. E-mail: seffetu@gmail.com

(C) Education \& Psychology I+D+i and Editorial EOS (Spain) 


\begin{abstract}
This review investigates how the unconscious information processing can create satisfactory learning outcomes, and can be used to ameliorate the challenges of teaching students to regulate their learning processes. The search for the ideal model of human information processing as regards achievement of teaching and learning objectives is a recurring issue in educational studies. Although conscious processes are more conducive to the objectives than unconscious processes, they do not necessarily result in satisfactory learning of instructional messages. Studies reviewed here show that the unconscious can play a facilitatory role in the encoding, storage, retrieval processes of information and learning activities, even when the conscious fails to achieve this. To take advantages of both conscious and unconscious processes, relevant literature suggests educators utilizing visual teaching aids that optimize use of working memory capacity and allow students to form mental imageries, thereby facilitating the comprehension of instructional messages.
\end{abstract}

Keywords: unconscious processes, conscious processes, information acquisition, mental imagery, visual information processing.

Received: 04/24/12

Initial acceptance: $15 / 06 / 12$

Final acceptance: 06/07/12 


\section{El papel de representaciones mentales en la adquisición de mensajes instruccionales.}

\section{Resumen}

Esta revisión investiga cómo el procesamiento de la información inconsciente, puede ayudar a crear resultados satisfactorios en el aprendizaje, y puede ser utilizado para mejorar los retos de enseñar a los alumnos para regular sus procesos de aprendizaje. La búsqueda del modelo ideal del procesamiento de la información humana, para delimitar los procesos y los objetivos de aprendizaje es un tema recurrente en los estudios educativos. A pesar de que los procesos conscientes son los más implicados para la consecución de los objetivos educativos y de la preocupación por estos procesos, ello no se ha traducido necesariamente en aprendizaje satisfactorio de las informaciones educativas. Los estudios revisados aquí muestran que el inconsciente puede jugar un papel facilitador en la codificación, el almacenamiento, procesos de recuperación de información y actividades de aprendizaje, aún cuando la conciencia no puede lograr este objetivo. Para aprovechar las ventajas delos procesos, tanto conscientes como inconscientes, la literatura sugiere que los educadores deben utilizan ayudas visuales de enseñanza que optimizan el uso de la capacidad de memoria de trabajo y permitir así a los estudiantes formar imaginarios mentales, lo que facilita la comprensión de los mensajes educativos.

Palabras clave: procesos inconscientes, procesos conscientes, adquisición de información, imaginarios mentales, procesamiento visual de la información. 


\section{Introduction}

The purpose of education is to change and effectively develop the ways in which students acquire information and learn (Farrell, 2010; Zimmerman, 2008). Students are able to engage in this process as conscious learners who can regulate their acquisition of information and motivate themselves to overcome failures in their learning processes (Dejonckheere, Van De Keere, \& Tallir, 2011). Students may hereby enhance their understanding of how successful learning occurs (Balcikanli, 2011; Forlin, 2010; Gaeta, Teruel, \& Orejudo, 2012). This conscious engagement of students in learning processes, however, does not necessarily result in satisfactory levels of achievement (De Bono, 1983; Dolati, Kuldaş, \& Mikaili, 2012).

A perusal review of relevant literature shows that conscious processes cannot persistently enable students to acquire and learn large quantities of provided messages (Lewicki, Hill, \& Czyzewska, 1992). However, unconscious mental processes such as mental imagery can allow students to integrate verbal and visual processing of instructional messages with each other (Paivio, 1991). Students can unconsciously engage in the encoding, storage, and retrieval processes of information and learn satisfactorily (Clark \& Paivio, 1991).

To allow the facilitatory rather than inhibitory role of unconscious information processing to take place in teaching and learning performances, relevant literature reviewed here suggests that educators use effective visual-teaching aids and allow students construct mental imagery, either consciously or unconsciously. Both conscious and unconscious mental imagery can help students translate complex verbal information into easy-to-grasp visual messages. In this assistance, it is essential to avoid simultaneous operation of sensory and cognitive information processing (Mayer, Moreno, Boire, \& Vagge, 1999), mismatch between teaching styles and teaching aids (Paas, Tuovinen, Tabbers, \& Van Gerven, 2003), and between verbal and visual instructional messages (Bodemer, Ploetzner, Feuerlein, \& Spada, 2004). Students thus can easily cope with the processing and learning of complex information (Paivio, 1991). Educators and educational researchers should therefore consider the capacity of unconscious processes to facilitate efficient teaching and learning outcomes (Thompson, 2004).

Casting light on the aforementioned arguments, this review has three aims. First, it draws attention to the role of the unconscious information processing in organization of information acquisition and learning processes. Second, it examines the question of how visual 
and verbal processing of instructional messages is mentally integrated with one another, resulting in satisfactory learning outcomes. And finally, it explicates how educators can enable students to meet the challenges in learning the ways to regulate their cognitive processes. These three aims are discussed in two main sections. The first section provides critical analysis of how conscious and unconscious processes organize human memory. This section further serves to elucidate the relationship between information acquisition and (a) the necessity of conscious awareness, (b) conscious control over perceptual processes, and (c) mental imagery in relation to visual information processing. The second section explores the educational implications arising from the unconscious processes of mental imagery and visual information processing, as regards the integration of verbal and visual instructional messages and the part these play in acquiring and learning information.

\section{Conscious and Unconscious Information Processing in Human Memory}

One of the distinguishing capabilities of humans is their sense of continuity between past and present experiences, which lays the foundations for human memory and learning (Phillips \& Singer, 1997). This continuity can be established through the conscious or the unconscious: the two ways in which learners encode, store, retrieve, and apply information in practice. However, the sense of continuity is mostly created by the unconscious rather than the conscious (Sternberg, 2003). The critical question here is therefore to what extent the conscious and unconscious processes organize human memory, thereby facilitating satisfactory learning (Sid \& Stanislas, 2007).

The least controversial view in this regard is that conscious processes are incapable of instantaneously responding to the majority of visual, audio, sensory, taste, or olfactory information for encoding, storage and retrieval in the human memory (Kihlstrom, 1987). This ability falls under the aegis of unconscious processes, ranging from perception to speech production (Jacoby \& Witherspoon, 1982), irrespective of personal characteristics (Hasher \& Zacks, 1984). A piece of unconsciously processed information can easily affect emotional experiences, thoughts, and behaviors before it fully enters into the conscious processes (Greenwald, Draine, \& Abrams, 1996). The conscious is therefore less involved in the major part of organization of human memory (Henningsen, 2010). Even where a conscious link is formed between past and present experiences, this link is fallible, as the unconscious also retains a sense of continuity between the desirability and undesirability of these events (Jou, 2011). Satisfac- 
toriness, unconscious needs, and expectations can determine what experiences are recalled or may be blocked in the memory (Westen, 2006). An undesirable memory, when triggered, is likely to be processed and blocked by a perceptual defense mechanism (Dahl, 2001; McGinnies, 1949; Pratto \& John, 1991; Robinson, Storbeck, Meier, \& Kirkeby, 2004; Taylor, 1991). The blocked experiences are likely to activate several cortical areas of the human brain (Blanco \& Soto, 2009; Siegel \& Weinberger, 2009), which unconsciously influence emotional information processing (Bargh \& Morsella, 2008; Meissner, 2006, 2008; Sid \& Stanislas, 2007). These unconscious influences prioritize more pleasant percepts, memories, and emotional meanings, through the exclusion of less satisfactory experiences, before they enter conscious processing (Weinberger \& Westen, 2008).

The aforementioned results demonstrate no clear distinction between the unconscious mental representations of memories and cognitive, automatic and controlled, information processing (Westen, 1999). This distinction, however, is crucial to understanding how the human memory acquires information (Bargh \& Chartrand, 1999; Bargh \& Ferguson, 2000), and how students can apply the acquired information to comprehending their environment. The most common consensus on these questions is that external information enters into short-term memory (STM) and long-term memory (LTM) through the sensory systems (Yuan, Steedle, Shavelson, Alonzo, \& Oppezzo, 2006). STM is the transitory storage of data, in which the working memory manipulates and stores limited information temporarily (Anderson, 2005). The capacity of the working memory is limited (Boston, Hale, Vasishth, \& Kliegl, 2011; Capraro, Capraro, \& Rupley, 2012), to the extent that humans are unable to respond to every piece of information consciously, or recognize all features and patterns of information simultaneously (Cassino, Taber, \& Lodge, 2007; Tversky \& Kahneman, 1981). Students therefore need to process or discern multiple patterns of information unconsciously, parallel to the conscious processes (Lewicki et al., 1992; Westen, 2006). The unconscious processes enable humans to integrate various cognitive patterns of information simultaneously, and to create associations with the consciously discerned information stored in permanent memory (Loftus \& Klinger, 1992). The unconscious processes thus comprise the conscious processes of working memory (Anderson, 1992; Squire, 1992) by strategically forming, retaining, and recalling the patterns of information in LTM (Chandler, 2004).

As a result of this, conscious and unconscious information processing can interact with each other in the information acquisition and learning processes (Anderson et al., 2004). 
Humans can be conscious of a small portion of the acquired information, particularly if the information was acquired consciously (Reber, 1989, 1992). The unconscious mental representations, however, can easily place such consciously acquired information into unconscious sets of knowledge structures by identifying and categorizing similar information (Anderson, 1992). The unconscious mental representations change the ways in which humans infer and learn a meaning from past and present experiences based on their own emotional states, expectations, fixed habits, preferred thoughts, and behavioral tendencies; this takes place before the meaning is fully demonstrated in their conscious awareness (Kihlstrom, 1987; Westen, 1999). These arguments raise the question of whether conscious awareness is necessary for the memory to acquire information and for successful learning to take place. This question is examined below.

Does the human memory require conscious awareness to acquire information from mental processes?

Cognitive psychologists and researchers face difficulties in investigating how neural activities of the brain enable human memory to acquire information from mental processes, imagery or representations (Lewicki, Czyzewska, \& Hoffman, 1987). The main difficulty lies in discerning whether people consciously select and classify information relating to their emotions, wishes, needs, and conflicts (Meissner, 2008). Neither researchers nor the subjects of their studies can observe the processes of information selection (Dolati et al., 2012), but nevertheless attempt to rationally explain these processes in terms of the emotional and motivational functions of the human psyche (Gilhooley, 2008).

Neuropsychological studies have shown that humans are unaware of how brain activities influence their subsequent thoughts and behaviors, particularly in establishing the emotional content of information such as fears, wishes, and conflicts (Gilhooley, 2008; Lewicki et al., 1987, 1992; Meissner, 2006, 2008; Sid \& Stanislas, 2007; Siegel \& Weinberger, 2009; Weinberger \& Westen, 2008; Westen, 1998, 1999, 2006). These emotional contents are unconsciously processed before entering into the conscious (Levy, 2003; Libet, 1999), that is, psychic processes that are considered to be conscious may go through a preliminary unconscious stage (Barsalou, 2003; Dolati et al., 2012). The psychic function of the human mind therefore cannot easily be exclusively restricted to conscious processes or separated from unconscious mental processes (Kihlstrom, 1987). 
Neuroscience and cognitive psychology, however, prefer to use the term "implicit processes" of human memory (e.g., Lewicki et al., 1987; Reber, 1989) when referring to the unconscious mental processes through which people implicitly acquire information and improve their individual and social skills. These implicit processes work associatively, allowing past experiences to exert an influence over ongoing experiences (Kihlstrom, Barnhardt, \& Tataryn, 1992; Lewicki, 1985; Reber, 1989; Rigoni, Kühn, Sartori, \& Brass, 2011; Schacter, 1992; Ziori \& Dienes, 2006). This is because all memory processes or experiences are implicitly associated, coded, or interlinked (Hasher \& Zacks, 1984). Activating a memory therefore stimulates related memories (Westen, 1999, 2006). For example, the word "wolf", or a picture of a wolf, can unconsciously activate an associated thought such as "predator or wildness." The same memory might unconsciously evoke either an undesirable or a desirable thought; in such cases, humans tend to accept the former and avoid the latter (Epstein, 1994; SalasAuvert \& Felgoise, 2003). The implicit processes are thus independent not only of conscious awareness, but also of intentional information acquisition and knowledge production (Banks \& Isham, 2009; Cleeremans, Destrebecqz, \& Boyer, 1998; Reber, 1992; Seger, 1994). However, Hammonds (2006) argued that, implicit processes do not occur without awareness but occur without verbal behaviour; an indication of awareness is mostly verbal behaviour of learning performance. Lack of verbal behaviour and the absence of awareness should be disassociated (Hammonds, 2006). Nevertheless, such a disassociation cannot be easily made because the absence of verbal behaviour might be perceived as the absence of attention. Verbal behaviour of implicit information acquisition demands more or less attention (Hartman, Knopman \& Wissen, 1989; Willingham \& Goedert-Eschmann, 1999). Accordingly, these results do not show exactly how the implicit processes can be disassociated from conscious processes (e.g., attention) and be differed from the unconscious mental processes. In particular, both, the implicit and the unconscious processes, utilize the same associative network of memory (e.g., wishes, beliefs, and fantasies) and procedures (e.g., motives and defenses), and these significantly affect subsequent feelings, thoughts, and behaviors (Westen, 1999).

Consequently, the memory has usually been considered a device to be employed consciously for the retrieval of information (Cassino et al., 2007). Not all stored information, however, is necessarily processed or retrieved consciously (Caplan \& Walter, 1996). The retrieval or the processes of information acquisition themselves often take place implicitly and incidentally, with no conscious awareness (Reber, 1992; Seger, 1994). Furthermore, the conscious processes of memory are incapable of instantly deriving complex information for ac- 
quisition from a task, while the implicit processes are capable of doing so (Lewicki et al., 1992). The implicit processes can therefore improve the performance of memory in the absence of conscious awareness (Ziori \& Dienes, 2006). This phenomenon can routinely be observed in human behavior (Westen, 1999). For instance, people are often unable to explain the process by which they correctly interpreted key elements of tasks, or how they arrived at conclusions that turned out to be accurate (Squire, 1992). This suggests that the acquired information itself is usually unconscious (Ziori \& Dienes, 2006), as is the process of information acquisition (Reber, 1989). Certain automatic processes, such as preconscious processing or priming, cannot be called into conscious awareness, irrespective of how much effort is made to do so (Chen \& Bargh, 1999; Johnston, McKague, \& Pratt, 2004). Accordingly, it appears possible that conscious awareness, conscious control, or conscious intention is not always accessible to cognitive and perceptual information processing to mediate the processes of information acquisition (Cleeremans et al., 1998). This possibility deserves closer scrutiny.

Is the human memory under conscious control and conscious intention when acquiring information from perceptual information processing?

Seger (1994) provided an overview of empirical findings, and maintained that the processes of perception and memory naturally work implicitly at the outset, preceding conscious processes (e.g., conscious awareness, control, and intention). The implicit processes are accordingly less affected by cognitive insults (e.g., brain injury, dementia, and amnesia). They are also relatively unaffected by error or missing data, and are evolutionarily older than the conscious processes in information and knowledge acquisition. Implicitly acquired knowledge structures respond visually to nonverbal perceptions, rely heavily on recognition of information patterns, facilitate the processing of complex information, and identify and disregard random elements very effectively. Seger (1994) therefore concluded that human memory is not primarily subject to conscious control or intention when acquiring information, nor is implicit information acquisition completely independent of attention and working memory capacity.

The implicit processes engage in information acquisition in response to a sphere of stimuli. This reactivates a set of neurons that obviates the need for conscious control and intention, collectively constructing a mental image of perceived information (Blanco \& Soto, 2009; Cleeremans et al., 1998) along with wishes, conflicted feelings, and unconscious de- 
fenses (Westen, 2006). Mental imagery thus manifests itself in neural networks of perception, allowing the human memory to acquire perceptual information unconsciously (Cohen et al., 1996). This interaction between the neural networks of perception and mental imagery eludes conscious awareness (Huettig \& McQueen, 2011; Thomson, Milliken, \& Smilek, 2010) and enables a set of neurons to retrieve information from the memory in order to respond to a stimulus. This not only alters the functional design of the information acquisition systems of memory (Salas-Auvert \& Felgoise, 2003), but also directs sensory and motor responses (Reber, 1989, 1992).

Accordingly, conscious intention and conscious control are dispensable for the human memory to acquire information. Moreover, an intention is not necessarily conscious (Chartrand \& Bargh, 1996). Implicit or automatic processes can activate memories, personal desires, and motives through a relevant stimulus, thereby activating intentions in the absence of conscious processes (Chartrand \& Bargh, 1996; Greenwald \& Banaji, 1995; Jacoby, Lindsay, \& Toth, 1992). The implicit processes are necessary as an automatic system that evaluates stimuli and reacts to them as quickly as possible without requiring the activation of conscious processes.

As a result, there is a significant overlap between the neural structures and cognitive mechanisms involved in mental imagery and those involved in perception (Kosslyn, Ganis, \& Thompson, 2001; Kosslyn \& Thompson, 2003). Where there is no overlap of mental imagery with perception, findings suggest that there is no mental imagery (Abell \& Currie, 1999; Bartolomeo, 2002; Pylyshyn, 2003). This overlap is not necessarily subject to conscious processes (McGinn, 2004). In other words, the interaction between perception and mental imagery is initiated implicitly or automatically, which allows the human memory to acquire information without conscious control and conscious intention. The relationship between mental imagery and the processes of information acquisition therefore requires elucidation.

\section{The role of mental imagery in information acquisition}

Information acquisition is an interacted multidimensional process that entails perceiving, forming, retaining, recalling, and applying information. In this process, emotions, thoughts, and behaviors occur associatively. The process enables the human mind to construct a mental image of perceived information, thereby deriving new ideas and concepts from men- 
tal imagery (Taylor, 1981). Human memory therefore acquires information from mental processes (Benson, 1997).

Mental imagery is a cognitive process of information acquisition that allows the reality of the world to be represented and grasped in the mind. The mind in turn can manipulate mental imagery quite freely to extract desired information, even when the subject is not actually being presented to the senses (Andrade, May, \& Kavanagh, 2009; Kavanagh, Andrade, \& May, 2005). Mental imagery of a desire therefore plays a key role in human behavior and motivation, as well as in their intention. Accordingly, it allows humans to process the world on two levels, abstract and concrete, by means of a type of pre-conceptual structure and function (Marks, 1999).

Mental imagery thus provides a sense of continuity between past and present experiences, laying the foundations of human memory, learning and conscious processes (Brewer \& Schommer-Aikins, 2006). This determinative role of mental imagery in molding everyday experiences or in all mental processes is uncontroversial (Eckardt, 1988). This role is central in visual-spatial reasoning and semantic grounding for language, which enables people to relate their past experiences to ongoing perceptual experiences: remembering, expecting, desiring, making decisions, and solving problems (Faw, 1997, 2009).

Memories of past experiences accordingly stimulate anticipation of prospective experiences, whether desired or undesired, thereby effectively reconstructing perceptual experiences and the processes underlying the memory (Jimerson, Brock, \& Pletcher, 2005). The effects of mental imagery are thus attributed to past experiences playing a manipulative motivational role in information acquisition (Paivio, 1991). Mental imagery might therefore be a manifestation of subjective experiences; but not exclusively, because mental imagery is a form of mental representation that underlies all experiences (Kosslyn, Thompson, \& Ganis 2006). Without mental representations, whether conscious or unconscious, people are unlikely to experience imagery or form memories through the association of past experiences with future possibilities (Paivio, 1986).

Mental representation itself is defined as implicit thought that lies behind the phenomena of incubation, intuition, and insight (Reber, 1989, 1992). Intuition arises in the absence of conscious processes; insight appears when unconscious thought is manifested into conscious- 
ness; and incubation is the process whereby unconscious thought becomes consciously accessible. An interaction within and between thoughts has the capacity to influence subsequent thoughts without being aware of it (Andersen, Glassman, Chen, \& Cole, 1995; Lewicki, 1985). However, these unconscious mental processes, describing how humans think, may require more or less consciously accessible knowledge of what to think of (Dienes, Broadbent, \& Berry, 1991; Perruchet \& Pacteau, 1991).

In practice, the experiential and representational concepts of mental imagery are frequently conflated. There also remains a lack of universal consensus regarding the nature of imagery experiences (Dennett, 2002; Kosslyn, 2005; Pylyshyn, 2002, 2003). The main controversy surrounding such imagery is whether or not it can be associated with a physical location in the brain (Bartolomeo, 2002; Bartolomeo \& Chokron, 2002; Berman \& Lyons, 2007; O'Regan \& Noë, 2001; Thomas, 1999). Some arguments go even further, claiming that the concept of imagery has no place in scientific ontology, and even that it has no scientific basis at all.

It has nevertheless been asserted that imagery may exist in the representational or visual modes of brain states (Kosslyn \& Thompson, 2003). Newton (1982), however, asserted that mental imagery is not merely a visual mode, but a mode of quasi-visual phenomena, similar to the quasi-perceptual experience in other sensory modes. Cognitive scientists recognize this assertion, as there is scientific evidence of motor or kinesthetic imagery, haptic or touch imagery, auditory imagery, and olfactory imagery (Bensafi et al., 2003; Jeannerod, 1994; Klatzky, Lederman, \& Matula 1991).

The evidence has thus shown that mental imagery appears in both sides of the human brain (Farah, 1995; Loverock \& Modigliani, 1995; Michimata, 1997; Sergent, 1990; Trojano $\&$ Grossi, 1994). The output of imagery reflected by the brain may then be processed and enriched to become a meaningful mental representation (Dennett, 2002; Kosslyn, 2005; Kosslyn et al., 2001; Rollins, 2001). Imagery can therefore be described as a unique form of mental representation (Kosslyn, 1976; Thomas, 2002) that influences percepts, imagination, emotions, behaviors, expressions, and fulfillment of desires. Information acquisition is unlikely to take place without memory processes being influenced by mental imagery and mental representation. The section below elaborates the effects of mental imagery on the effectiveness of 
students in processing and responding to various forms of information in the classroom environment.

\section{The Role of Unconscious Mental Imagery in the Educational Implications of Visual In- formation Processing}

In order to investigate the ways in which the human memory acquires information, it is necessary to elucidate how cognitive activities (e.g., visual and verbal manipulations, mental imagery, or mental representations) interact with each other (Paivio, 1991). One basic hypothesis states that the cognitive processing of information unconsciously initiates a variety of changes in mental imagery and mental representations, thereby implicitly altering the way in which the memory acquires information (Mayer \& Anderson, 1992). When students respond cognitively to information presented in a classroom, their response is invariably produced in cooperation with various perceptions of motivational variables (e.g., enjoyability of classrom climate) (Phan, 2008) and mental representations (Clark \& Paivio, 1991). In particular, it is necessary to investigate to what extent students effectively process and respond to various forms of information and mental processes such as imagery and representations (Mayer \& Moreno, 2002).

This issue has become much more significant as our understanding has improved regarding the limited capacity of the conscious processes underlying human memory (Dolati et al., 2012; Smith, 2003; Ten Dam \& Volman, 2004). This particularly affects the working memory, visual and verbal, which has a significant role in teaching and learning, and which influence the efficiency of information processing and response production (De Bono, 1983; Mayer, 1999). The limited capacity may be effective for the verbal and visual working memory to function, if the verbal and visual messages are not excessively complex (Baddeley, 1992; Bodemer, et al., 2004; Mayer \& Moreno, 2002), but are presented to students through visual and verbal modalities simultaneously rather than separately (Mayer \& Anderson, 1992; Mayer et al., 1999). This capacity proves inadequate when the information, which is highly complex, excessive, and requires instantaneous responses, goes through only one sensory modality (Pollock, Chandler, \& Sweller, 2002; Schnotz, Böckheler, \& Grzondziel, 1999; Sweller, 1993; Sweller \& Chandler, 1994), or when it is presented through inappropriate instructional materials and teaching methods (Chandler \& Sweller, 1991, 1992; Paas et al., 2003; Paas, Renkl, \& Sweller, 2004; Sweller, Merriënboer, \& Paas, 1998). In or- 
der to respect this limitation, the memory capacity should not be overloaded (Mayer \& Moreno, 2002). This leaves students more cognitive energy with which to establish connections between the visual and verbal information presented (Kalyuga, Chandler, \& Sweller, 1999; Mayer, Heiser, \& Lonn, 2001). In addition, students need to adequately rehearse the information (Schneider \& Shiffrin, 1977), as this process allows them to create a single unit from the discrete packets of information, and to make the retrieval of learned information automatic (Shiffrin \& Schneider, 1977). This automation enables students to process, remember, and react effectively to more information (Anderson, 1992). Furthermore, remembering conceptual or semantic features facilitates retrieval of associated information patterns (Anderson, Budiu, \& Reder, 2001; Hofmeister, 2011).

What students remember might not be the direct meaning of the information presented in the classroom, but another meaning they already knew or which they have inferred (Bransford \& Johnson, 1972; Lowe, 1999), onto which they have imposed personalized interpretations (Mcloughlin, 2009). Students can easily infer meanings based on the ways by which information is encoded and stored in long-term memory. This profoundly affects the processing of information in the working memory. Accordingly, if, at the beginning of a lesson, educators present information patterns that activate information patterns already learned, students are more likely to retrieve the correct information (Ranzijn, 1991). This in turn may facilitate understanding and integration of information learned up to that point.

It should be noted that students do not create meaning directly from presented instructional messages, but rather they experience, construct, and represent information through signs (Cunningham, 1992). Signs allow students to represent or interpret the objects; thus signs, objects, and students are the structural components of knowledge constructions (Cunningham, 1992; Driscoll \& Lebow, 1992). Accordingly, if students are assisted in building their own signs and generating knowledge of the objects or items presented, they can automatically engage in learning activities, facilitating their understanding and making inferences (Winn, Hoffman, \& Osberg, 1995).

Educators can encourage these processes by providing students with visual instructional materials that incorporate images or symbols into texts (Winn, 1982). This enables students to mentally represent or manipulate the imagery values of the presented texts (Winn, 1980), forging a link between long-term and working memory. The more images educators 
integrate into the relevant content of the text, the more effectively students will be able to navigate information in the classroom environment (Paivio, 1991). The use of appropriate visual materials (i.e., realistic pictures depicting the contents of a text) can also be beneficial to educators for identification of teaching tasks, such as line drawings for teaching activities (Kleinman \& Dwyer, 1999), and to those students who have basic knowledge for the tasks (Lowe, 1996; Wood \& Endres, 2004).

The question that arises relating to visual materials is how best to integrate verbal and visual messages, thereby facilitating rapid and accurate learning (Mayer, 2001). One suggestion is to establish a conceptual connection between visual and verbal imagery, between pictures and texts (Schnotz, 1993). The illustration of texts with corresponding pictures effectively assists the memory in the tasks of encoding, storing, and retrieval (Clark \& Paivio, 1991). This allows the joint retention of the two information types, thus facilitating the understanding of students (Kulhavy, Lee, \& Caterino, 1985).

The visual information processing system of the human memory engages in encoding and decoding the imagery values of verbal information, thereby appropriately incorporating these features into each other and yielding satisfactorily learning outcomes (Paivio, 1991, 2007). This system enables students to easily recall information from the visual presentations, even where they cannot recall it from the verbal presentations (Carney \& Levin, 2002). In addition, the system provides students with an imagery or visual style of learning whereby they acquire and apply information without conscious awareness, as the process operates unconsciously (Clark \& Paivio, 1991).

Through the visual system, a corresponding type of stimulus implicitly activates a particular type of memory code, particularly when an associative link has been established (Grainger, 1998). For example, the word "wolf" sets the verbal code in motion, while images of the wolf activate the visual code. In this case, the image can activate the corresponding word and vice versa by associative processes of the system. The system thus comprises the verbal values of information, thereby converting them into the imagery codes in two ways, abstract and concrete, resulting in visualizing smells, sounds, tastes, and sensation of touch (Chandler \& Sweller, 1991; Mayer, 2001; Mayer \& Anderson, 1992). This operation particularly relates to comprehension or instructive forms of reading, writing, knowing and communication (Paivio, 1991). 
Another example to show how the visual system unconsciously integrate texts and images with each other is the reading process; as you are reading these propositions you are not aware of that the unconscious processes have already provided you with the integration of blank "spaces" or "cavities", which are between and within different letters (e.g., "y" "o", and "u"), with the "lines" of the letters, thereby constructing the image of "you", as a word. Such imagery codes of words further enable us to unconsciously construct and organize a relationship between the "gaps", which are between the words (e.g., you " " are " " reading " " these " "words), with the words, thereby making sentences. From the microsecond, it would be impossible for us to be consciously aware of whether it is from the spaces and cavities or from the lines that we start to discern verbal and visual messages, unless there is unconscious integration of the spaces and cavities with the lines along. Our mind is unlikely to measure and determine the size of each space, cavity, line, gap, and word, and simultaneously manipulate and integrate them with one another by instantaneously and persistently prioritizing conscious awareness. The mind is not constantly conscious of what organizes the memory and how it operates the information. The unconscious processes of mental imagery therefore might be responsible for these processes. All the spaces, cavities, gaps and lines of letters are visual and verbal values, which are integrated by mental imagery without requiring our conscious awareness. The unconscious processes thus enable us to create an unconscious image of what we are writing and reading, and hence to integrate and discern their imagery and verbal meanings unconsciously and later consciously.

The letters accordingly become the concrete images of the words that facilitate the construction of both symbolical and conceptual meanings. The interaction within and between imagery and verbal values in the visual system allows the meanings of experiences to be generated and interpreted (Rieber, 1994), thereby playing a role in accelerating knowledge acquisition or knowledge construction (Chun \& Plass, 1996). The interaction may implicitly evoke different information from that intended; however learning occurs more readily than without the interactions (Koren, 1999). This also pushes students towards unconscious associative processes when reinterpreting their thoughts or ideas from one mode of representation to another. The interaction further increases the likelihood of retention and fosters richness of recall (Chun \& Plass, 1996).

Accordingly, visual processing can manipulate and retain any type of information without necessarily requiring conscious awareness. It thus facilitates interpretation, compre- 
hension, and insight (Mayer, 2001; Snyder \& Colon, 1988). Such processing furthermore enhances communicative ability, as well as improving performance in specific skills such as problem-solving (Mayer \& Anderson, 1992). The visual system thus enhances memory processes, visual abilities, and thinking skills, thereby increasing the effectiveness of teaching and learning performance (Hegarty \& Just, 1993; Levie \& Lentz, 1982). Wood and Endres (2004) suggested that as students develop their visual ability to imagine, elaborate, predict, and confirm, they grasp the meaning of information more comprehensively. This is because the system allows students to acquire and make sense of information unconsciously, providing an alternative to conscious information acquisition (Winn, 1987).

In order to take advantage of the visual system to improve the performance of students in teaching and learning activities, it has been concluded that more visual teaching aids should be used (Chandler \& Sweller, 1991; Mayer, 2001). This means that imagery values should be integrated into text in textbooks, classroom presentations, instructional manuals, and computer-based instruction materials (Kleinman \& Dwyer, 1999). The visual aids involve real objects in teaching, such as charts, maps, graphics, diagrams, film strips, slides and pictures that facilitate the teaching process. These illustrate relevant scenarios that raise the emotions of students and force them to act unconsciously (McCann \& Garcia, 1999). The aids are, therefore, tools used to improve teaching performance by motivating students to want to read assigned texts, both expository and narrative (Wood \& Endres, 2004).

Kleinman and Dwyer (1999) showed reliable evidence that specific visual aids promote achievement of learning, particularly when learning a concept. Students may make sense of a concept when the aids illustrate a form of concept in relation to its content and context (Heinich, Molenda, Russell, \& Smaldino, 1999). This conveys the meaning of the concept with regard to its conceptual form. If a concept is used without its context, many interpretations and differences in learning appear, because a concept may have different types of representation of meanings (Chun \& Plass, 1997; Clark \& Paivio, 1991; Schnotz, 1993). Conceptual learning depends mainly on the meaning of the concepts, where they belong or to what they refer (Koda, 1989). Concepts that refer directly to their contents or meanings may facilitate comprehension, particularly when they are interrelated with one another (Laufer \& Sim, 1985). The comprehension of concepts mostly depends on their mental imagery value (Danan, 1992). The imagery value of concepts follows directly from reading a concept in its context, provided that the reading process is undisturbed. This supplies readers with a desired or pre- 
ferred meaning through conscious processes. However, meanings are not necessarily learned best from the kinds of imagery value that students prefer to view consciously (Heinich et al., 1999).

In order to reduce such detrimental effects of students' preference, instructional messages should rely on the most concrete words or concepts that are highly loaded with imagery values. The more concrete words are, and the higher their imagery values, the easier it is to illustrate the words and their meanings (Beishuizen, Stoutjesdijk, Spuijbroek, Bouwmeester, \& Van Der Geest, 2002). If concepts or words are highly and appropriately loaded with their imagery values, this significantly facilitates more correct interpretation and learning than for those with low and inappropriate imagery value loading, even if there is no conscious intention of forming relevant imagery values (Danan, 1992; Koren, 1999; Paivio, 1991). It has furthermore been shown that if features of the imagery values are dissimilar to one another, the involvement of conscious processes in scanning the imagery features is low; but if the imagery features are similar to each other, the involvement of conscious scanning processes is high (Borst \& Kosslyn, 2008). Any pictorial or textural value of information is more readily accessible to the unconscious than conscious. The unconscious processes of mental imagery and visual information processing can therefore potentially enable students to integrate verbal and imagery values of presented instructional messages with each other and to learn their meanings effectively (Danan, 1992).

\section{Conclusion}

The ways in which the human memory acquire information consist in perceptual, cognitive, and mental processes that form the interactions between the human body and mind, between perceptions, emotions, motives, thoughts, behaviours, and learning. Most parts of these multidimensional processes can be implicitly associated or interacting with one another, but they can also engage in more or less conscious activities such as conscious awareness, attention, intention, and control. These conscious processes cannot be highly effective in instantaneously processing the majority of information or in readily organizing the memory, but the unconscious processes can be effective. The unconscious can work either in the absence or in the presence of the conscious, evaluating information and facilitating the performance of information acquisition. The memory is not always necessarily subject to the conscious activities at the outset or in the sequal of encoding and storage processes of information. 
The unconscious processes of mental imagery and visual information processing engage the various senses in information acquisition and lead learning to occur much more easily and satisfactorily, thereby facilitating teaching performance. Through the use of proper visual teaching aids, the unconscious allows educational utilization of these multidimensional processes, that is, to help students effectively to encode, store, retrieve, and apply information, motivate them to learn more efficiently, and to enable them to grasp the contextual relation between verbal and visual instructional messages, deriving meanings from the verbal and imagery values of processed information. Thus, the unconscious can significantly accelerate the information acquisition and facilitate the occurrence of satisfactory learning.

In order to preclude detrimental effects on teaching and learning performance, which might result from the simultaneous operation of various senses, it is crucial to avoid teaching styles inappropriate for the visual aids, the presentation of excessive information, and irrelevancy between verbal and visual messages. These could otherwise overload the cognitive and mental processes, thereby hindering satisfactory information acquisition and learning. The more appropriate the presentation of the imagery values of verbal information, the better students will be able to acquire information and learn meaningfully. 


\section{References}

Abell, C., \& Currie, G. (1999). Internal and external pictures. Philosophical Psychology, 12(4), 429-445. doi:10.1080/095150899105675

Andersen, S. M., Glassman, N. S., Chen, S., \& Cole, S. W. (1995). Transference in social perception: The role of chronic accessibility in significant-other representations. Journal of Personality and Social Psychology, 69(1), 41-57. Retrieved from http://doi.apa.org/journals/psp/69/1/41.pdf

Anderson, J. R. (1992). Automaticity and the ACT* theory. American Journal of Psychology, 105(2), 165-180. Retrieved from http://www.jstor.org/stable/1423026

Anderson, J. R. (2005). Human symbol manipulation within an integrated cognitive architecture. Cognitive Science, 29(3), 313-341. Retrieved from http://csjarchive.cogsci.rpi.edu/2005v29/index.html

Anderson, J. R., Bothell, D., Byrne, M. D., Douglass, S., Lebiere, C., \& Qin, Y. (2004). An integrated theory of the mind. Psychological Review, 111(4), 1036-1060. doi:10.1037/0033-295X.111.4.1036

Anderson, J. R., Budiu, R., \& Reder, L. (2001). A theory of sentence memory as part of a general theory of memory. Journal of Memory and Language, 45, 337-367. doi:10.1006/jmla.2000.2770

Andrade, J., May, J., \& Kavanagh, D. (2009). Conscious and unconscious processes in human desire. Psyche, 15(2), 83-91. Retrieved from http://eprints.qut.edu.au/28523/1/c28523.pdf

Baddeley, A. D. (1992). Working memory. Science, 255(5044), 556-559. doi:10.1126/science.1736359

Balcikanli, C. (2011). Metacognitive awareness inventory for teachers (MAIT). Electronic Journal of Research in Educational Psychology, 9(3), 1309-1332.

Banks, W. P. \& Isham, E. A. (2009). We infer rather than perceive the moment we decided to act. Psychological Science, 20(1), 17-21. doi:10.1111/j.1467-9280.2008.02254.x

Bargh, J. A., \& Chartrand, T. L. (1999). The unbearable automaticity of being. American Psychologist, 54(7), 462-479. doi:10.1037/0003-066X.54.7.462

Bargh, J. A., \& Ferguson, M. J. (2000). Beyond behaviorism: On the automaticity of higher mental processes. Psychological Bulletin, 126(6), 925-945. doi:10.1037//00332909.126.6.925 
Bargh, J. A., \& Morsella, E. (2008). The unconscious mind. Perspectives in Psychological Science, 3(1), 73-79. doi:10.1111/j.1745-6916.2008.00064.x

Barsalou, L. (2003). Situated simulation in the human conceptual system. Language and Cognitive Processes, 18(5-6), 513-562. doi:10.1080/01690960344000026

Bartolomeo, P. (2002). The relationship between visual perception and visual mental imagery: A reappraisal of the neuropsychological evidence. Cortex, 38, 357-378. doi:10.1016/S0010-9452(08)70665-8

Bartolomeo, P., \& Chokron, S. (2002). Can we change our vantage point to explore imaginal neglect? Behavioral and Brain Sciences, 25, 184-185. doi:10.1017/S0140525X02240042

Beishuizen, J., Stoutjesdijk, E., Spuijbroek S., Bouwmeester, S., \& Van Der Geest, H. (2002). Understanding abstract expository texts. British Journal of Educational Psychology, 72(2), 279-297. doi:10.1348/000709902158892

Bensafi, M., Porter, J., Pouliot, S., Mainland, J., Johnson, B., Zelano, C., ...Sobel, N. (2003). Olfactomotor activity during imagery mimics that during perception. Nature Neuroscience, 6, 1142-1144. doi:10.1038/nn1145

Benson, P. J. (1997). Problems in picturing text: A study of visual/verbal problem solving. Technical Communication Quarterly, 6(2), 141-160. doi:10.1207/s15427625tcq0602_2

Berman, D., \& Lyons, W. (2007). The first modern battle for consciousness: J. B. Watson's rejection of mental images. Journal of Consciousness Studies, 14(11), 4-26. Retrieved from http://www.imprint.co.uk/jcs_14_11.html

Blanco, M. J., \& Soto, D. (2009). Unconscious perception of a flash can trigger line motion illusion. Experimental Brain Research, 192(4), 605-613. doi:10.1007/s00221-008$1564-9$

Bodemer, D., Ploetzner, R., Feuerlein, I., \& Spada, H. (2004). The active integration of information during learning with dynamic and interactive visualizations. Learning and Instruction, 14(3), 325-341. doi:10.1016/j.learninstruc.2004.06.006

Borst, G., \& Kosslyn, S. M. (2008). Visual mental imagery and visual perception: Structural equivalence revealed by scanning processes. Memory \& Cognition, 36(4), 849-862. doi:10.3758/MC.36.4.849 
Boston, M. F., Hale, J. T., Vasishth, S., \& Kliegl, R. (2011). Parallel processing and sentence comprehension difficulty. Language and Cognitive Processes, 26(3), 301-349. doi:10.1080/01690965.2010.492228

Bransford, J. D., \& Johnson, M. K. (1972). Contextual prerequisites for understanding: Some investigations of comprehension and recall. Journal of Verbal Learning and Verbal Behavior, 11, 717-726. Retrieved from http://memlab0.eng.yale.edu/PDFs/1972_Bransford_Johnson_JVLVB.pdf

Brewer, W. F., \& Schommer-Aikins, M. (2006). Scientists are not deficient in mental imagery: Galton revised. Review of General Psychology, 10, 130-146. doi:10.1037/10892680.10.2.130

Caplan, D., \& Walter, G. S. (1996). Syntactic processing in sentence comprehension under dual-task conditions in aphasic patients. Language and Cognitive Processes, 11(5), 525-551. doi:10.1080/016909696387141

Capraro, R. M., Capraro, M. M., \& Rupley, W. H. (2012). Reading-enhanced word problem solving: A theoretical model. European Journal of Psychology of Education, 27(1), 91-114. doi:10.1007/s10212-011-0068-3

Carney, R. N., \& Levin, J. R. (2002). Pictorial illustrations still improve students' learning from text. Educational Psychology Review, 14(1), 5-26. doi:10.1023/A:1013176309260

Cassino, D., Taber, C. S., \& Lodge, M. (2007). Information processing and public opinion. Politische Vierteljahresschrift, 48(2), 205-220. doi:10.1007/s11615-007-0044-3.

Chandler, P. (2004). The crucial role of cognitive processes in the design of dynamic visualizations. Learning and Instruction, 353-357. doi:10.1016/j.learninstruc.2004.06.009

Chandler, P., \& Sweller, J. (1991). Cognitive load theory and the format of instruction. Cognition and Instruction, 8(4), 293-332. doi:10.1207/s1532690xci0804_2

Chandler, P., \& Sweller, J. (1992). The split-attention effect as a factor in the design of instruction. British Journal of Educational Psychology, 62(2), 233-246. doi:10.1111/j.2044-8279.1992.tb01017.x

Chartrand, T. L., \& Bargh, J. A. (1996). Automatic activation of impression formation and memorization goals: Nonconscious goal priming reproduces effects of explicit task 
instructions. Journal of Personality and Social Psychology, 71(3), 464-478. doi:10.1037/0022-3514.71.3.464

Chen, M., \& Bargh, J. A. (1999). Consequences of automatic evaluation: Immediate behavioral predispositions to approach or avoid the stimulus. Personality and Social Psychology Bulletin, 25(2), 215-224. doi:10.1177/0146167299025002007

Chun, D. M., \& Plass, J. L. (1996). Effects of multimedia annotations on vocabulary acquisition. The Modern Language Journal, 80(2), 183-198. Retrieved from http://www.jstor.org/stable/328635

Chun, D. M., \& Plass, J. L. (1997). Research on text comprehension in multimedia environments. Language Learning Technology, 1(1), 60-81. Retrieved from http://llt.msu.edu/vol1num1/chun_plass/default.html

Clark, J. M., \& Paivio, A. (1991). Dual coding theory and education. Educational Psychology Review, 3(3), 149-210. doi:10.1007/BF01320076

Cleeremans, A., Destrebecqz, A., \& Boyer, M. (1998). Implicit learning: News from the front. Trends in Cognitive Sciences, 2(10), 406-416. doi:10.1016/S1364-6613(98)01232-7

Cohen, M. S., Kosslyn, S. M., Breiter, H. C., DiGirolamo, G. J., Thompson, W. L., Anderson, A. K., ...Belliveau J. W. (1996). Changes in cortical activity during mental rotation: A mapping study using functional MRI. Brain, 119, 89-100. Retrieved from http://brain.oxfordjournals.org/content/119/1/89.full.pdf

Cunningham, D. J. (1992). Beyond educational psychology: Steps towards an educational semiotic. Educational Psychology Review, 4(2), 165-194. doi:10.1007/BF01322343

Dahl, M. (2001). Asymmetries in the processing of emotionally valenced words. Scandinavian Journal of Psychology, 42(2), 97-104. doi:10.1111/1467-9450.00218

Danan, M. (1992). Reversed subtitling and dual coding theory: New directions for foreign language instruction. Language Learning, 42(4), 497-527. doi:10.1111/j.14671770.1992.tb01042.x

De Bono, E. (1983). The direct teaching of thinking as a skill. Phi Delta Kappa International, 64(10), 703-708. doi:10.2307/20386870

Dejonckheere, P., Van De Keere, K., \& Tallir, I. (2011). Are fourth and fifth grade children better scientists through metacognitive learning? Electronic Journal of Research in Educational Psychology, 9(1), 133-156. 
Dennett, D. C. (2002). Does your brain use the images in it, and if so, how? Behavioral and Brain Sciences, 25, 189-190. doi:10.1017/S0140525X02290044

Dienes, Z., Broadbent, D., \& Berry, D. C. (1991). Implicit and explicit knowledge bases in artificial grammar learning. Journal of Experimental Psychology: Learning, Memory, \& Cognition, 17(5), 875-887. doi:10.1037/0278-7393.17.5.875

Dolati, I., Kuldaş, S., \& Mikaili, P. (2012). Teaching how to think under unconscious process. Journal of Basic and Applied Scientific Research, 2(4), 3693-3703. Retrieved from http://www.textroad.com/JBASR-April,\%202012\%283\%29.html

Driscoll, M., \& Lebow, D. (1992). Making it happen: Possibilities and pitfalls of Cunningham's semiotic. Educational Psychology Review, 4(2), 211-221. doi:10.1007/BF01322345

Eckardt, V. B. (1988). Mental images and their explanations. Philosophical Studies, 53, 441460. Retrieved from http://www.jstor.org/stable/4319963

Epstein, S. (1994). Integration of the cognitive and the psychodynamic unconscious. American Psychologist, 49(8), 709-724. doi:10.1037/0003-066X.49.8.709

Farah, M. J. (1995). Current issues in the neuropsychology of image generation. Neuropsychologia, 33(11), 1455-1471. doi:10.1016/0028-3932(95)00075-E

Farrell, P. (2010). School psychology: Learning lessons from history and moving forward. School Psychology International, 31(6), 581-598. doi:10.1177/0143034310386533

Faw, B. (1997). Outlining a brain model of mental imaging abilities. Neuroscience and Biobehavioral Reviews, 21(3), 283-288. doi:10.1016/S0149-7634(96)00026-7

Faw, B. (2009). Conflicting intuitions may be based on differing abilities: Evidence from mental imaging research. Journal of Consciousness Studies, 16(4), 45-68. Retrieved from http://www.imprint.co.uk/jcs/

Forlin, C. (2010). The role of the school psychologist in inclusive education for ensuring quality learning outcomes for all learners. School Psychology International, 31(6), $617-$ 630. doi:10.1177/0143034310386535

Gaeta, M. L., Teruel, M. P., \& Orejudo, S. (2012). Metacognitive awareness inventory for teachers (MAIT). Electronic Journal of Research in Educational Psychology, 10(1), 073-094. 
Gilhooley, D. (2008). Psychoanalysis and the cognitive unconscious: Implications for clinical technique. Modern Psychoanalysis, 33A, 91-127. Retrieved from http://www.pepweb.org/search.php?author=Gilhooley\%2C+D.

Grainger, J. (1998). Masked priming by translation equivalents in proficient bilinguals. Language and Cognitive Processes, 13(6), 601-623. doi:10.1080/016909698386393

Greenwald, A. G., \& Banaji, M. R. (1995). Implicit social cognition, attitudes, self-esteem, and stereotypes. Psychological Review, 102(1), 4-27. doi:10.1037/0033-295X.102.1.4

Greenwald, A. G., Draine, S. C., \& Abrams, R. L. (1996). Three cognitive markers of unconscious semantic activation. Science, 273(5282), 1699-1702. doi:10.1126/science.273.5282.1699

Hammonds, F. (2006). Toward an "awareness" of the relationship between task performance and own verbal accounts of that performance. The Analysis of Verbal Behavior, 22(1), 101-110. Retrieved from http://www.ncbi.nlm.nih.gov/pmc/articles/PMC2774592/

Hartman, M., Knopman, D. S., \& Nissen, M. J. (1989). Implicit learning of new verbal associations. Journal of Experimental Psychology: Learning, Memory, and Cognition, 15(6), 1070-1082. doi:10.1037/0278-7393.15.6.1070

Hasher, L., \& Zacks, R. T. (1984). Automatic processing of fundamental information: The case of frequency of occurrence. American Psychologist, 39(12), 1372-1388. doi:10.1037/0003-066X.39.12.1372

Hegarty, M., \& Just, M. A. (1993). Constructing mental models of machines from text and diagrams. Journal of Memory and Language, 32(6), 717-742. doi.org/10.1006/jmla.1993.1036

Heinich, R., Molenda, M., Russell, J. D., \& Smaldino, S. E. (1999). Instructional media and technologies for learning (6th ed.). Upper Saddle River, NJ: Prentice-Hall.

Henningsen, H. P. (2010). How the NETofANs-model explains representation, intentionality, and much of the process that generates the contents of awareness. Neurocomputing, 74(1-3), 57-75. doi:10.1016/j.neucom.2009.10.032

Hofmeister, P. (2011). Representational complexity and memory retrieval in language comprehension. Language and Cognitive Processes, 26(3), 376-405. doi:0.1080/01690965.2010.492642 
Huettig, F., \& McQueen, J. M. (2011). The nature of the visual environment induces implicit biases during language-mediated visual search. Memory \& Cognition, 39(6), 10681084. doi:10.3758/s13421-011-0086-z

Jacoby, L. L., Lindsay, D. S., \& Toth, J. P. (1992). Unconscious influences revealed: Attention, awareness, and control. American Psychologist, 47, 802-809. doi:10.1037/0003066X.47.6.802

Jacoby, L. L., \& Witherspoon, D. (1982). Remembering without awareness. Canadian Journal of Psychology, 36(2), 300-324. doi:10.1037/h0080638

Jeannerod, M. (1994). The representing brain: Neural correlates of motor intention and imagery. Behavioral and Brain Sciences, 17(2), 187-202. doi:10.1017/S0140525X00034026

Jimerson, S. R., Brock, S. E., \& Pletcher, S. W. (2005). An integrated model of school crisis preparedness and intervention: A shared foundation to facilitate international crisis intervention. School Psychology International, 26(3), 275-296. doi:10.1177/0143034305055974

Johnston, M., McKague, M., \& Pratt, C. (2004). Evidence for an automatic orthographic code in the processing of visually novel word forms. Language and Cognitive Processes, 19(2), 273-317. doi:10.1080/01690960344000189

Jou, J. (2011). Conscious and unconscious discriminations between true and false memories. Consciousness and Cognition, 20(3), 828-839. doi:10.1016/j.concog.2010.10.022

Kalyuga, S., Chandler, P., \& Sweller, J. (1999). Managing split-attention and redundancy in multimedia learning. Applied Cognitive Psychology, 13(4), 351-371.

Kavanagh, D. J., Andrade, J., \& May, J. (2005). Imaginary relish and exquisite torture: The elaborated intrusion theory of desire. Psychological Review, 112(2), 446-467. doi:10.1037/0033-295X.112.2.446

Kihlstrom, J. F. (1987). The cognitive unconscious. Science, 237, 1445-1452. doi:10.1126/science.3629249

Kihlstrom, J. F., Barnhardt, T. M., \& Tataryn, D. J. (1992). The psychological unconscious: Found, lost, and regained. American Psychologist, 47(6), 788-791. doi:10.1037/0003066X.47.6.788 
Klatzky, R. L., Lederman, S. J., \& Matula, D. E. (1991). Imagined haptic exploration in judgements of object properties. Journal of Experimental Psychology: Learning, Memory, and Cognition, 17(2), 314-322. doi:10.1037/0278-7393.17.2.314

Kleinman, E. B., \& Dwyer, F. M. (1999). Analysis of computerized visual skills: Relationships to intellectual skills and achievement. International Journal of Instructional Media, 26(1), 53-69. Retrieved from http://www.adprima.com/ijim.htm

Koda, K. (1989). The effect of transferee vocabulary knowledge on the development of L2 reading proficiency. Foreign Language Annals, 22(6), 529-540. doi:10.1111/j.19449720.1989.tb02780.x

Koren, S. (1999). Vocabulary instruction through hypertext: Are there advantages over conventional methods of teaching? The Electronic Journal for English as a Second Language, $4(1), \quad 1-14 . \quad$ Retrieved from http://www.teslej.org/wordpress/issues/volume4/ej13/ej13a2/

Kosslyn, S. M. (1976). Can imagery be distinguished from other forms of internal representation? Evidence from studies of information retrieval times. Memory and Cognition, 4(3), 291-297. doi:10.3758/BF03213178

Kosslyn, S. M. (2005). Mental images and the brain. Cognitive Neuropsychology, 22(3-4), 333-347. doi:10.1080/02643290442000130

Kosslyn, S. M., Ganis, G., \& Thompson, W. L. (2001). Neural foundations of imagery. Nature Reviews: Neuroscience, 2(9), 635-642. doi:10.1038/35090055

Kosslyn, S. M., \& Thompson, W. L. (2003). When is early visual cortex activated during visual imagery? Psychological Bulletin, 129, 723-746. doi:10.1037/00332909.129.5.723

Kosslyn, S. M., Thompson, W. L., \& Ganis, G. (2006). The case for mental imagery. Oxford: Oxford University Press.

Kulhavy, R. W, Lee, J. B., \& Caterino, L. C. (1985). Conjoint retention of maps and related discourse. Contemporary Educational Psychology, 10(1), 28-37. doi:10.1016/0361476X(85)90003-7

Laufer, B., \& Sim. D. D. (1985). An attempt to measure the threshold of competence for reading comprehension. Foreign Language Annals, 18(5), 405-411. doi:10.1111/j.19449720.1985.tb00973.x 
Levie, W. H., \& Lentz, R. (1982). Effects of text illustrations: A review of research. Educational Communications and Technology Journal, 30(4), 195-232. doi:10.1007/BF02765184

Levy, D. (2003). How to psychoanalyze a robot: Unconscious cognition and the evolution of intentionality. Minds and Machines, 13(2), 203-212. doi:10.1023/A:1022958611684

Lewicki, P. (1985). Nonconscious biasing effects of single instances on subsequent judgments. Journal of Personality and Social Psychology, 48(3), 563-574. doi:10.1037/0022-3514.48.3.563

Lewicki, P., Czyzewska, M., \& Hoffman, H. (1987). Unconscious acquisition of complex procedural knowledge. Journal of Experimental Psychology: Learning, Memory, and Cognition, 13(4), 523-530. doi:10.1037/0278-7393.13.4.523

Lewicki, P., Hill, T., \& Czyzewska, M. (1992). Nonconscious acquisition of information. American Psychologist, 47, 796-801. doi:10.1037/0003-066X.47.6.796

Libet, B. (1999). Do we have free will? Journal of Consciousness Studies, 6(8-9), 47-57. Retrieved from http://ingentaconnect.com/search/article?option1=tka\&value 1=do+we+have+free+will \&pageSize $=10 \&$ index $=1$

Loftus, E. F., \& Klinger, M. R. (1992). Is the unconscious smart or dumb? American Psychologist, 47(6), 761-765. doi:10.1037/0003-066X.47.6.761

Loverock, D. S., \& Modigliani, V. (1995). Visual imagery and the brain: A review. Journal of Mental Imagery, 19(1-2), 91-132. Retrieved from http://www.journalofmentalimagery.com/backissues3.html\#19a

Lowe, R. K. (1996). Background knowledge and the construction of a situational representation from a diagram. European Journal of Psychology of Education, 11(4), 377-397. doi:10.1007/BF03173279

Lowe, R. K. (1999). Extracting information from an animation during complex visual learning. European Journal of Psychology of Education, 14(2), 225-244. doi:10.1007/BF03172967

Marks, D. F. (1999). Consciousness, mental imagery and action. British Journal of Psychology, 90(4), 567-585. doi:10.1348/000712699161639

Mayer, R. E. (1999). Research-based principles for the design of instructional messages. Document Design, 1, 7-19. doi:10.1075/dd.1.1.02may 
Mayer, R. E. (2001). Multimedia learning. New York, Cambridge: Cambridge University Press.

Mayer, R. E., \& Anderson, R. B. (1992). The instructive animation: Helping students build connections between words and pictures in multimedia learning. Journal of Educational Psychology, 84(4), 444-452. doi:10.1037/0022-0663.84.4.444

Mayer, R. E., Heiser, J., \& Lonn, S. (2001). Cognitive constraints on multimedia learning: When presenting more material results in less understanding. Journal of Educational Psychology, 93(1), 187-198. doi:10.1037/0022-0663.93.1.187

Mayer, R. E., \& Moreno, R. (2002). Aids to computer-based multimedia learning. Learning and Instruction, 12(1), 107-119. doi:10.1016/S0959-4752(01)00018-4

Mayer, R. E., Moreno, R., Boire, M., \& Vagge, S., (1999). Maximizing constructivist learning from multimedia communications by minimizing cognitive load. Journal of Educational Psychology, 91(4), 638-643. doi:10.1037/0022-0663.91.4.638

McCann, E. J., \& Garcia, T. (1999). Maintaining motivation and regulating emotion: Measuring individual differences in academic volitional strategies. Learning and Individual Differences, 11(3), 259-279. doi:10.1016/S1041-6080(99)80003-X

McGinn, C. (2004). Mindsight: Image, dream, meaning. Cambridge, MA: Harvard University Press.

McGinnies, E. (1949). Emotionality and perceptual defence. Psychological Review, 56(5), 244-251. doi:10.1037/h0056508

Mcloughlin, C. S. (2009). Characteristics of students failing medical education: An essay of reflections. Medical Education Online, 14, 1-6. doi:10.3885/meo.2009

Meissner, W. W. (2006). Psychoanalysis and the mind-body relation: Psychosomatic perspectives. Bulletin of the Menninger Clinic, 70(4), 295-315. doi:10.1521/bumc.2006.70.4.295

Meissner, W. W. (2008). Mind-brain and consciousness in psychoanalysis. Bulletin of the Menninger Clinic, 72(4), 283-312. doi:10.1521/bumc.2008.72.4.283

Michimata, C. (1997). Hemispheric processing of categorical and coordinate spatial relations in vision and visual imagery. Brain and Cognition, 33(3), 370-387. doi:10.1006/brcg.1997.0875

Newton, N. (1982). Experience and imagery. The Southern Journal of Philosophy, 21(4), 475487. doi:10.1111/j.2041-6962.1982.tb00314.x 
O'Regan, J. K., \& Noë, A. (2001). A sensorimotor account of vision and visual consciousness. Behavioral and Brain Sciences, 24(5), 939-973. doi:10.1017/S0140525X01000115

Paas, F., Renkl, A., \& Sweller, J. (2004). Cognitive load theory: Instructional implications of the interaction between information structures and cognitive architecture. Instructional Science, 32(1-2), 1-8. doi:10.1023/B:TRUC.0000021806.17516.d0

Paas, F., Tuovinen, J. E., Tabbers, H. K., \& Van Gerven, P. W. M. (2003). Cognitive load measurement as a means to advance cognitive load theory. Educational Psychologist, 38(1), 63-71. doi:10.1207/S15326985EP3801_8

Paivio, A. (1986). Mental Representations: A dual coding approach. New York: Oxford University Press.

Paivio, A. (1991). Dual coding theory: Retrospect and current status. Canadian Journal of Psychology, 45(3), 255-287. doi:10.1037/h0084295

Paivio, A. (2007). Mind and its evolution: A dual coding theoretical approach. Mahwah, NJ: Erlbaum.

Perruchet, P., \& Pacteau, C. (1991). The implicit acquisition of abstract knowledge about artificial grammar: Some methodological and conceptual issues. Journal of Experimental Psychology: General, 120(1), 112-116. doi:10.1037/0096-3445.120.1.112

Phan, H. P. (2008). Achievement goals, the classroom environment, and reflective thinking: A conceptual framework. Electronic Journal of Research in Educational Psychology, 16(6), 571-602.

Phillips, W. A., \& Singer, W. (1997). In search of common foundations for cortical computation. Behavioral and Brain Sciences, 20(4), 657-683. Retrieved from http://journals.cambridge.org/action/displayIssue?decade=1990\&jid=BBS\&volumeId $=20 \&$ issueId $=04 \&$ iid $=29254$

Pollock, E., Chandler, P., \& Sweller, J. (2002). Assimilating complex information. Learning and Instruction, 12(1), 61-86. .doi:10.1016/S0959-4752(01)00016-0

Pratto, F., \& John, O. P. (1991) Automatic vigilance: the attention-grabbing power of negative social information. Journal of Personality and Social Psychology, 61(3), 380-391. doi:10.1037/0022-3514.61.3.380

Pylyshyn, Z. W. (2002). Mental imagery: In search of a theory. Behavioral and Brain Sciences, 25(2), 157-182. doi:10.1017/S0140525X02000043 
Pylyshyn, Z. W. (2003). Return of the mental image: Are there really pictures in the brain? Trends in Cognitive Sciences, 7(3), 113-118. doi:10.1016/S1364-6613(03)00003-2

Ranzijn, F. J. A. (1991). The sequence of conceptual information in instruction and its effect on retention. Instructional Science, 20(5-6), 405-418. doi:10.1007/BF00116356

Reber, A. S. (1989). Implicit learning and tacit knowledge. Journal of Experimental Psychology: General, 118(3), 219-235. doi:10.1037/0096-3445.118.3.219

Reber, A. S. (1992). An evolutionary context for the cognitive unconscious. Philosophical Psychology, 5(1), 33-51. doi:10.1080/09515089208573042

Rieber, L. P. (1994). Computers, graphics and learning. Madison, WI: WCB Brown \& Benchmark

Rigoni, D., Kühn, S., Sartori, G., \& Brass, M. (2011). Inducing disbelief in free will alters brain correlates of preconscious motor preparation: The brain minds whether we believe in free will or not. Psychological Science, 22(5), 613-618. doi:10.1177/0956797611405680

Robinson, M. D., Storbeck, J., Meier, B. P., \& Kirkeby, B. S. (2004). Watch out! That could be dangerous: Valence-arousal interactions in evaluative processing. Personality and Social Psychology Bulletin, 30(11), 1472-1484. doi:10.1177/0146167204266647

Rollins, M. (2001). The strategic eye: Kosslyn's theory of imagery and perception. Minds and Machines, 11(2), 267-286. doi:10.1023/A:1011239208090

Salas-Auvert, J. A., \& Felgoise, S. H. (2003). The rational-experiential information processing system model: it's implication for cognitive therapy. International Journal of Clinical and Health Psychology, 3(1), 123-140. Retrieved from http://www.aepc.es/ijchp/articulos_pdf/ijchp-64.pdf

Schacter, D. L. (1992). Understanding implicit memory: A cognitive neuroscience approach. American Psychologist, 47(4), 559-569. doi:10.1037/0003-066X.47.4.559

Schneider, W., \& Shiffrin, R. M. (1977). Controlled and automatic human processing: I. detection, search and attention. Psychological Review, 84(1), 1-66. doi:10.1037/0033295X.84.1.1

Schnotz, W. (1993). On the relation between dual coding and mental models in graphics comprehension. Learning and Instruction, 3(3), 247-249. doi:10.1016/09594752(93)90008-N 
Schnotz, W., Böckheler, J., \& Grzondziel, H. (1999). Individual and co-operative learning with interactive animated pictures. European Journal of Psychology of Education, 14(2), 245-265. doi:10.1007/BF03172968

Seger, C. (1994). Implicit learning. Psychological Bulletin, 115(2), 163-196. doi:10.1037/0033-2909.115.2.163

Sergent, J. (1990). The neuropsychology of visual image generation: Data, method, and theory. Brain and Cognition, 13(1), 98-129. doi:10.1016/0278-2626(90)90043-N

Shiffrin, R. M., \& Schneider, W. (1977). Controlled and automatic information processing: II. Perceptual learning, automatic attending, and a general theory. Psychological Review, 84(2), 127-90. doi:10.1037/0033-295X.84.2.127

Sid, K., \& Stanislas, D. (2007). Levels of processing during non-conscious perception: A critical review of visual masking. Philosophical Transactions of the Royal Society, $B$ 362(1481), 857-875. doi:10.1098/rstb.2007.2093

Siegel, P., \& Weinberger, J. (2009). Very brief exposure: The effects of unreportable stimuli on fearful behavior. Consciousness and Cognition, 18(4), 939-951. doi.org/10.1016/j.concog.2009.08.001

Smith, G. F. (2003). Beyond critical thinking and decision making: Teaching business students how to think. Journal of Management Education, 27(1), 24-51. doi:10.1177/1052562902239247

Snyder, H., \& Colon, I. (1988). Foreign language acquisition and audio-visual aids. Foreign Language Annals, 21(4), 343-384. doi:10.1111/j.1944-9720.1988.tb01079.x

Squire, L. R. (1992). Declarative and nondeclarative memory: multiple brain system supporting learning and memory. Journal of Cognitive Neuroscience, 4(3), 232-243. doi:10.1162/jocn.1992.4.3.232

Sternberg, R. J. (2003). Cognitive psychology (3rd ed.). Belmont, CA: Thomson \& Wadsworth.

Sweller, J. (1993). Some cognitive processes and their consequences for the organisation and presentation of information. Australian Journal of Psychology, 45(1), 1-8. doi:10.1080/00049539308259112

Sweller, J., \& Chandler, P. (1994). Why some material is difficult to learn. Cognition and Instruction, 12(3), 185-233. doi:10.1207/s1532690xci1203_1 
Sweller, J., Van Merriënboer, J., \& Paas, F. (1998). Cognitive architecture and instructional design. Educational Psychology Review, 10, 251-296. doi:10.1023/A:1022193728205

Taylor, P. (1981). Imagination and information. Philosophy and Phenomenological Research, 42(2), 205-223. Retrieved from http://www.jstor.org/stable/2107292

Taylor, S. E. (1991). Asymmetrical effects of positive and negative events: the mobilizationminimization hypothesis. Psychological Bulletin, 110(1), 67-85. doi:10.1037/00332909.110.1.67

Ten Dam, G., \& Volman, M. (2004). Critical thinking as a citizenship competence: teaching strategies. Learning and Instruction, 14(4), 359-379. doi:10.1016/j.learninstruc.2004.01.005

Thomas, N. J. T. (1999). Are theories of imagery theories of imagination? An active perception approach to conscious mental content. Cognitive Science, 23, 207-245. doi:10.1207/s15516709cog2302_3

Thomas, N. J. T. (2002). The false dichotomy of imagery. Behavioral and Brain Sciences, 25(2), 211-211. doi:10.1017/S0140525X02510049

Thompson, J. L. (2004). Innovation through people. Management Decision, 42(9), 10821094. doi:10.1108/00251740410565127

Thomson, D. R., Milliken, B., \& Smilek, D. (2010). Long-term conceptual implicit memory: A decade of evidence. Memory \& Cognition, 38(1), 42-46. doi:10.3758/MC.38.1.42

Trojano, L., \& Grossi, D. (1994). A critical review of mental imagery defects. Brain and Cognition, 24, 213-243. doi:10.1006/brcg.1994.1012

Tversky, A., \& Kahneman, D. (1981). The framing of decisions and the psychology of choice. Science, New Series, 211(4481), 453-458. doi:10.1126/science.7455683

Weinberger, J., \& Westen, D. (2008). RATS, we should have used Clinton: Subliminal priming in political campaigns. Political Psychology, 29(5), 631-651. doi:10.1111/j.1467-9221.2008.00658.x

Westen, D. (1998). The scientific legacy of Sigmund Freud: Toward a psychodynamically informed psychological science. Psychological Bulletin, 124(3), 333-371. doi:10.1037/0033-2909.124.3.333

Westen, D. (1999). The scientific status of unconscious processes: is Freud really dead? Journal of the American Psychoanalytic Association, 47(4), 1061-1106. doi:10.1177/000306519904700404 
Westen, D. (2006). Implications of research in cognitive neuroscience for psychodynamic psychotherapy, Focus 4(2), 215-222. Retrieved from http://psychiatryonline.org/article.aspx?articleid=50573

Willingham D. B., \& Goedert-Eschmann, K. (1999). The relation between implicit and explicit learning: Evidence for parallel development. Psychological Science, 10(6), 531534. doi:10.1111/1467-9280.00201

Winn, W. D. (1980). Visual information processing: A pragmatic approach to the imagery question. Educational Communication and Technology, 28(2), 120-133. Retrieved from http://www.jstor.org/stable/30218025

Winn, W. D. (1982). Visualization in learning and instruction: A cognitive approach. Educational Communication and Technology, 30(1), 3-25. Retrieved from http://www.jstor.org/stable/30219822

Winn, W. D. (1987). Instructional design and intelligent systems: Shifts in the designer's decision-making role. Instructional Science, 16(1), 59-77. doi:10.1007/BF00120006

Winn, W., Hoffman, H., \& Osberg, K. (1995). Semiotics and the design of objects, actions and interactions in virtual environments. Proceedings of annual meeting of American educational research association, San Franciso, CA, pp. 21. Retrieved from http://www.eric.ed.gov/PDFS/ED385236.pdf

Wood, K. D., \& Endres, C. (2004). Motivating student interest with the imagine, elaborate, predict, and confirm (IEPC) strategy. The Reading Teacher, 58(4), 346-357. doi:10.1598/RT.58.4.4

Yuan, K., Steedle, J., Shavelson, R., Alonzo, A., \& Oppezzo, M. (2006). Working memory, fluid intelligence, and science learning. Educational Research Review, 1, 83-98. doi:10.1016/j.edurev.2006.08.005

Zimmerman, B. J. (2008). Investigating self-regulation and motivation: Historical background, methodological developments and future prospects. American Educational Research Journal, 45(1), 166-183. doi:10.3102/0002831207312909

Ziori, E., \& Dienes, Z. (2006). Subjective measures of unconscious knowledge of concepts. Mind \& Society, 5, 105-122. doi:10.1007/s11299-006-0012-4 